Journal of World Englishes and Educational Practices (JWEEP)

ISSN: 2707-7586

DOI: 10.32996/jweep

Website: https://al-kindipublisher.com/index.php/jweep/index

\title{
Gender Role and Supervisory Styles of Public-School Heads
}

Rosalinda A. $\operatorname{Tan}^{1}$, Rex T. Argate*2, and Harline L. Barcoso ${ }^{3}$,

${ }^{1}$ District Supervisor, Department of Education - Cebu City Division, Cebu City, Philippines

${ }^{2}$ Chairperson, College of Teacher Education \& Graduate School, University of Cebu - Main, Cebu City, Philippines

${ }^{3}$ Faculty, Senior High School Department, University of Cebu - Main, Cebu City, Philippines

Corresponding Author: Rex T. Argate, E-mail: rargate@uc.edu.ph

ARTICLE INFO

Received: November 12, 2020

Accepted: December 10, 2020

Volume: 2

Issue: 6

DOI: 10.32996/jweep.2020.2.6.1

\section{KEYWORDS}

gender, supervisory styles, school heads, leadership

\section{ABSTRACT}

The study focused on the administrative and supervisory functions of male and female school heads in public schools of Cebu City Division. The key informants were school heads and teachers from sixteen districts in Cebu City Division. The school head informants were chosen according to the number of administrative and instructional experience. The school heads had at least five years leadership experience. The teacher informants were chosen at random by the researcher. The main instrument of the study was the researcher and the key informants. The study utilized interview guides covering different areas of administrative management and instructional leadership function. In administrative management the informants were interviewed about the distinct practices of male and female school heads involving human research management, physical facilities management, fiscal management, data management, linkage management, communication and conflict management. In instructional leadership function, the key informants talked about the distinct practices of male and female school heads in instructional supervision, curriculum leadership and staff development. Based on the findings of the study, the following propositions were drawn: one, administrative function could be gauged by physical facilities, teacher behavior and student development; two, instructional leadership is contributed by learning performance outcome and teacher competence; third, gender bears the administrative function and instructional leadership. From the different propositions mentioned, this theory was generated, Tan's Gender Role Orientation Theory of Institutional Management. After the conduct of the study and the theory generated, it is revealed that administrative and instructional leadership styles of male and female school heads can be influenced by gender orientation.

\section{Introduction}

In today's climate of heightened expectations, school heads are in the hot seat to improve teaching and learning through customized and strengthened leadership and supervisory styles (Gardiner, 2009). However, in the performance of their leadership and supervisory roles, critical issues like gender differences, expectations and roles are central features that confront the dynamic operations of schools in producing desired educational outcomes.

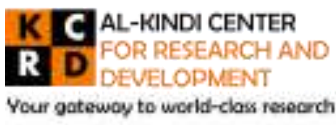

Published by Al-KindiCenter for Research and Development. Copyright (c) the author(s). This is an open access article under CC BY license (https://creativecommons.org/licenses/by/4.0/) 
Although the Department of Education (DepEd) does not give premium at the moment, on the processes of how school heads manage their schools with reference to gender and sexual orientations, the ability to lead and supervise a highly female dominated organization appears to be an influential factor in the operational processes of schools.

Schools today are mostly operated by females as compared way back when teaching profession was still enticing to men in the 18th century schools (Bass, 2008). Statistics of the department show that more than 80 percent of the teaching positions are occupied by females. The same goes in school leadership. In Cebu City alone, the Department of Education tallies 93 percent female school heads than their male counterparts.

The current statistics show a large disparity of gender participation in the affairs of schools which favor female participation in the teaching profession of basic Education (Vecchio, 2002). This may have led to the presumption that the role of education in the primary, elementary and secondary schools are primarily in the hands of the female teachers.

The early years' workforce is still skewed dramatically toward women as a result of deeply ingrained gender stereotypes. Researches by Nottingham Trent University and Bedfordshire University have found that most male teachers are confident working with older children instead (Manning, 2002), as compared to younger children with female teachers. But the study suggests that a number of consistent stereotypes and barriers stop many men from entering the profession in the first place.

Eagly (2002) points out that male and female school heads have varying degrees of competencies and approaches in the leadership dimensions of schools. In fact, several programs are given by the department to best improve these qualities of leadership and supervision, ranging from the capability building programs, graduate programs and supervisory programs. All intended to improve skills in leadership, although, uncertain on whether or not, these programs address gender needs of these leaders.

However, in the course of duty of these school heads, the Department of Education, particularly, the Cebu City Division has noted multiple concerns and or conflicts concerning management and leadership styles and supervision. These conflicts are diverse in nature that involve male to male interaction, female to female, and male to female interaction and vice versa.

It is interesting to presume that gender may have played a crucial component in these conflicts. If so, it may be interesting to investigate how gender orientation influences leadership and supervisory styles of school heads. Although, the department has not been too akin in finding out the relationship between conflict management and/or supervisory styles and gender orientation of school heads as an interest in exploring the possibilities of the said connections. Hence, appropriated and customized interventions to school heads are sought with reference to gender orientations.

The acute need to prepare our school heads to handle situation the complex operation of schools that comprise both men and women has been the focus of this study. The need to find out how men and women handle several leadership dimensions in schools like management, communication, conflict, direction setting, and decision-making has compelled the conduct of this study with an end in view of formulating interventions that best fit the gender needs of school leaders in the exercise of their leadership and supervisory functions.

Should the relationship between gender and leadership and supervisory styles be established, the researcher, who is occupying supervisory position will help facilitate the formulation of intervention programs in leadership and management emphasizing the gender roles and orientation of school heads, hence, reducing significantly the conflicting incidences between and among school leaders and teachers.

\section{Philosophical Stance}

No researcher enters the field with totally blank sheet but rather would have his or her own disciplinary trainings that provide perspectives from which to investigate the problem. These different bodies of knowledge supply theoretical sensitivity that support understanding of data that were being collected during the research process. Thus, philosophical basis is required in conducting the study to provide grounding on the perceptual perspective on what to look for and on how to methodologically describe the phenomenon. Leadership styles are not entirely dependent on external factors. Some authors have proposed that leadership styles are highly correlated with personality type which in turn some have claimed is related to gender (Appelbaum, 2003). Thus, it discusses the ontological, epistemological, axiological, methodological and rhetorical assumptions of qualitative research as important framework of the study. 


\section{Ontological Assumption}

Oncology is concern with what kind of world we are investigating, the nature of existence, and the structure of reality. Guba (1989) state that the ontological assumptions are those that respond to the question 'what is there that can be known?' or 'what is the nature of reality?'

With these given definitions of ontology, let us now identify the ontology used in the study. The study uses an ontology which is essentially of a social world of meanings. In this world, the researcher assumes that the world she investigates is a world populated by human beings who have their own thoughts, interpretations and meanings. The researcher investigates this reality with the use of the different research methods and techniques of the interpretive design such as interviews, surveys, and observations, in order to interpret the key informants' inner thoughts and feelings.

The researchers believe that realities are constructed by the social actors which realities are relative that no reality is considered truer than any other; these realities are within the context of the social actors' lives.

The study also adopts a realistic ontology which follows the physical world in which an assumption on the existence of a world of causes an effect. It is not the ontology of mechanical causes that may catch in the cause-effect relationships. But, on this study, an assumption is made that there are some realities which exist in the world and may affect the supervisory styles of the public-school heads.

\section{Epistemological Assumption}

Understanding and explaining how we know what we know is the domain of epistemology (Crotty, 2003). Epistemology is concern with providing a philosophical grounding that can help in deciding what kinds of knowledge are possible and how we can ensure that these knowledges are both adequate and legitimate (Maynard, 1994).

The first Epistemological stance used in the study is constructionism. In the constructivists' perspective, knowledge is constructed as the product of the interaction between man and his world and is developed and transmitted within the social context (Crotty, 2003). Therefore, meaning is constructed rather than being discovered.

The study also uses objectivism as the epistemological stance. According to objectivist epistemology meaningful reality exists as such independent from the operation of the any consciousness (Crotty, 2003). It means that the mind of the investigator is thought to be separate of the world of objects, on what is investigated, as used in this study.

\section{Axiological Assumptions}

The axiological assumption has to do with values. Positivists believe that the process of research is free of values, because they consider themselves as independent of the study. They are interested in the interrelationship between the objects they are studying and they believe that their research does not affect these objects in any way. On the other hand, interpretivists subscribe to the idea that the researcher has values that help him figure out what is considered to be facts and help him interpret them (Hussey, 2009).

The researchers believe that values are inevitable and desirable. Often, research has a value-laden purpose. The researchers are not hesitant to be openly fervent about pursuing the project. Due to the inevitability of biases, they have to include personal interpretations together with the participants' interpretation.

\section{Methodological Assumption}

Methodology refers to a plan of action, system, procedure or strategy that lies behind the choice and use of specific methods and links the choice and use of methods to the expected out (Crotty, 2003). Its aim is to evaluate, justify and describe the use of particular methods (Wellington, 2000).

The methodological approach is concern with the research process. In a positivist-oriented research, the concepts should be explained in a way that they can be measured. It uses large samples, focuses on objective facts and phrases hypotheses. The interpretivist-oriented research is done through examining a small sample during a certain period of time. The analysis 
conducted should be able to understand what is happening in a situation and find patterns that are present in other situations (Hussey, 2009).

\section{Rhetorical Assumption}

Rhetorical assumption according to Hussey (2009) has to do with the language of research. For positivists, the style is normally formal and is illustrated in passive voice. This is done in order to create an impression that research is more objective from what is publicly known. The language of research for interpretivists is less explicit; normally it is appropriate to write in first person reflecting that the researcher is involved in what is being researched. However, it depends on the persons who are writing the research paper, to ensure the objectivity of the results of the study.

The language utilized by the researcher is personal and engaging. This includes the use of the definition of terms which is defined operationally. Some terms in the text have multiple definitions including multiple definitions provided by the participants.

The adopted ontology and epistemology in this research accept that knowledge is not static, but it is always emerging and transforming, and it is interpreted by both researcher and the key informants. Meaning is conveyed through a dialogue and action. Within a dialogue and action are the embedded understanding, experience, and emotion. Only through interaction and discourse can meaning be unlocked and conveyed to the key informants. From this perspective, descriptive narrative provides a method which enables the researcher to adduce true meaning and understanding of data.

To provide a complete and appropriate context for the investigation of the problem in this study, a comprehensive discussion is made in order to provide a guide for thorough investigation with high sense of motivation. The motivation leading to this inquiry is an interest in the gender role and supervisory styles of public-school heads. To bring this motivation closer to the fulfillment of this inquiry, the main concept is divided into sections with the following sub concepts: distinct practices of male and female school heads along administrative leadership functions, distinct practices of male and female school heads along instructional leadership functions, and the issues and challenges male and female school heads confront in dealing with their personnel.

\section{Domains of Inquiry}

The study explored how gender roles influence the supervisory styles of school heads of Cebu City Division. To achieve this thesis statement, the study aimed to:

a. narrate the distinct practices of male and female school heads along administrative leadership functions;

b. narrate the distinct practices of male and female school heads along instructional leadership functions;

c. discuss issues and challenges that male and female school heads confront in dealing with their personnel; and

d. generate a theory based on the result of the study.

\section{Methodology}

This study utilized an exploratory qualitative research using naturalistic design. As a qualitative approach, it dispossessed the use of research tools to quantify measures of responses and perceptions of the chosen key informants; instead, it utilized focused group interviews, interview guide, naturalistic observations, and field notes, to generate information and data as practiced by the key informants in their regular work. Triangulation was also utilized to validate responses from different key informants and with the use of secondary data.

Since the study utilized qualitative research, there were 10 School Heads who were selected as primary key informants (PKIs) in the study. They were selected using a convenient sampling. They were assigned to elementary and secondary schools in the city. Out of the ten school heads five were males and five were females and all of them had at least three years of administrative and instructional experience. There were three teachers under each school head who were also utilized as Secondary Key Informants (SKIs), making use of 30 SKIs in all. Ten of these SKIs were males and the remaining twenty were females. The PKIS were selected according to number of years where they performed managerial and supervisory functions. They should have at least five years managerial and supervisory experience. They were chosen from different districts in Cebu City division. The PKIs were chosen at random and they have possessed at least three years teaching experience and under the supervision of the PKIs. Table 1 reflects the profiles of the selected PKIs. 
The study utilized interview guides and observation checklist which were being prepared and were validated by experts. There were two (2) types of interview guides. One was intended for the administrative leadership functions of the PKIs and the other one was intended for their instructional leadership functions.

The gathering of data was done using interview guide as the primary tool. The interview was conducted to the 10 PKIs selected in the study. Before the interview permission was secured from the office of Dean of the Graduate School, for the approval of the Schools Division Superintendent (SDS). After getting the approval from the two officers, the proposed study was submitted to the Institutional Review Board (IRB) to check the ethical concerns in the study. The study was subjected to a series of revisions before it was approved and a go signal was given to proceed with the generation of data. As part of the ethical consideration, PKIs and SKIs where given the informed content to secure before the gathering of data was conducted. Then, the interview was conducted on them. The Focus Group Discussions (FGDs) and the recorded observation were conducted with SKIs of the ten selected PKIs, in order to validate responses primarily taken from them. Afterwards, the data were collated, analyzed and interpreted and then the findings, conclusions, and recommendations were derived.

\section{Discussion}

\subsection{Distinct Practices of Male and Female School Heads along Administrative Leadership Functions}

By definition, school heads performed various functions which were not instructional in nature. These included human resource, physical facilities, financial, linkage, data and conflict management. The performance of school heads, along these functions, would crop up when they badly needed this performance. While, there was no specified time when these functions have to take place; but, the primary determinants in the exercise of these functions were the clients. In the case of the schools, the teachers, students and community were the direct clients of the school heads.

\subsubsection{Human Resource Management}

In the interview conducted among key informants, it was revealed that male school heads assigned teachers with regular functions according to capability, experience and maturity while female counterpart assigned teachers according to performance and specialization. On assigning leadership functions to teachers both male and female school heads agreed that integrity, competence and experience were the integral considerations though male school leaders did not give much priorities on trustworthiness issues. Both male and female school heads do not have that much difference based on assigning tasks to teachers. Both had determining criteria that were not much different from the other.

In the interview conducted among key informants, it was revealed that male school heads assigned teachers with regular functions according to capability, experience and maturity while female counterpart assigned teachers according to performance and specialization. On assigning leadership functions to teachers both male and female school heads agreed that integrity, competence and experience were the integral considerations though male school leaders did not give more priorities on trustworthiness issues. Both male and female school heads did not have that much difference based on assigning tasks to teachers. Both had determining criteria that were not much different from the other.

When asked about the reason why school heads normally assigned female teachers to become guidance counselor and treasurer, they said "those female teachers had more experience in handling budgetary concerns and family related issues" (SKI2). On the issue of males being assigned to areas that required strength and control, the teachers pointed out that "males normally were seen as a symbol of power which was equivalent to strength" (SKI-7). Males did not typically indulge themselves to nitty gritty things and minor details of affairs either in the family or in school. Budgeting and behavioral issues about children in school were complex issues and normally males did not take care of them.

Said perceptions about what a male and female could do in schools were practically influenced by the typical functions of the family members. Said functions had also been used in the workplace with a perceived mindset that what a male and female could do well in the family could also be replicated in the school level.

Harris (2002) cited the national opinion poll that female holders of political offices were especially suited for pursuing what could be regarded as the communal goals of public policy on dealing with children and family problems, assisting the poor and working for peace while male office holders were especially suited for pursuing what could be regarded as agented goals of public policy on directing the military and handling big business, domestic rebellion, economy and foreign policies. 


\subsubsection{Physical Facilities Management}

The key informants of this study revealed through rigorous interviews that both male and female school heads claimed to have practiced this function to the best of their abilities although results showed differences. Both male and female school heads preferred to have good physical conditions for most of the facilities. They believed that facilities having a good condition would have a direct impact on the performance of their students. Although in terms of preference the male school head would like to have a classroom which was simple, neat and orderly while the female counterpart preferred to have well decorated classrooms that would address the intricacies of the learners' needs.

The preference in classroom setting and decorations was perceived to have been influenced by the stereotype that the Filipino culture had attributed to male and female members of the community. While the community assigned males to simple and direct orientations to any forms of engagements, females, on the other hand, were oriented on intricate matters of family affairs taking into consideration even the aesthetic side of things.

On the other hand, attending to the needs to secure the necessary facilities for operation, maintaining its care and maximizing the utilization of the above-cited facilities were claimed to have been performed by both male and female school heads. They both recognized that this job ate up most of their functions considering the meager provisions of the department. They were compelled to partner with institutions and individuals who were potential providers of the facilities that they needed. However, in terms of processes on securing the needed facilities, female school heads according to outside sources, were more aggressive in utilizing their social skills.

\subsubsection{Fiscal Management}

The SKIs included in this study revealed that in the area of financial management, both male and female school leaders preferred to have female teachers to handle the finances of the schools. They both believed that with female teachers to handle the finances, the resources of the school were in good hands. The preference over female finance officers were attributed to security and safety. Further, both leaders claimed that they observed transparency in all the financial transactions by means of communicating the expenditures to all stakeholders in the school. However, in the interview it was noted that female school heads monitor more frequently the finance operations handled by their officer than their male counterparts.

London (2002) pointed out that the dominance of choice over female finance officers were attributed due to their experience in handling the finances of their families. Females normally tend to do the budgeting functions of the family and take care of utilizing the funds until the next month. The said expectation was highly probable among females than male who were expected to perform functions that require strength and power. The common perception among male and female school heads designating female finance officers in the school was perceived to have been influenced by role expectation in the family and community. Congruity of functions to norms and standards even in the workplace was still strong in the Philippine schools although sporadic instances were noted in few schools all throughout.

\subsubsection{Linkage Management}

To the PKIs and SKIs of this study, linkage management was a fundamental task that needs immediate action considering the inadequacy of school resources. To them, they all had exerted various efforts to generate resources through partnership although the method they used may vary according to their individual capacities. Generally, they claimed that they used common methods in partnership and linkage management by use of common office communication like letters, simple proposals and simple face to face interaction. They all had used their personal connections through a process called stakeholders' inventory. The immediate connections of their staff and friends had also contributed to widening their network and possible support organizations. However, according to the PKIs 1, 2, 6 \& 9, they had differentiated their strategies when it comes to maintaining the sustainable support of their network. The female leaders had the tendency to flaunt partners' relationship through regular conversations and strong hospitality measures while male school leaders had fewer engagements in terms of social interaction and conversations

In communication styles, male and female school leaders preferred face to face meetings and phone calls. Outside the organization both male and female school leaders maintained sound relationships. They networked with individuals and organizations because they felt it was their responsibility to represent their schools and addressed what was inadequate in their schools through partnership. Males spent 22 to 38 percent and female school leaders spent 20 to 40 percent of their work time networking with peers and colleagues (Helgesen, 1990). 


\subsubsection{Data Management}

School Heads revealed that they all performed the tasks on collecting, correcting and validating data while updating regularly the said information. They also communicated this information through various means like conferences, presentations and meetings by using technology oriented medium. They all claimed that they utilized the data in their day-to-day decision making. However, they also had the tendency to deposit voluminous data collections in the information depository.

\subsubsection{Communication and Conflict Management}

During the interview the teachers expressed that female school heads were more caring, nurturing and concerned about the needs of others than their male counterpart. The teachers explained that these traits enabled the faculty to talk about concerns or situations about home because a female school head had better understanding of all the responsibilities. It was indicated that the caring traits helped to create a support system between the school head and the teachers which in return reduced the possibility of conflicts in the organization.

\subsection{Distinct Practices of Male and Female School Heads along Instructional Leadership Functions}

The discussion below presents the peculiar practices of male and female school heads in the area of instructional supervision, curriculum management, and staff development. The descriptions are taken from the key informants themselves and from the interviews with people working directly with them like their teachers and supervisors.

\subsubsection{Instructional Supervision}

To the teacher informants, female school heads expressed differently their value on student growth. To them, a female school head regularly held meetings with teachers to discuss concerns pertaining to instructional concerns related to student growth. The teachers remarked that they could approach more easily a female school head than its male counterpart. This was attributed to the fact that most teachers are females and that they shared more commonalities to their immediate female school heads than the male teachers who wanted to share with school heads having similar gender with them.

Female school heads can be more detailed in a post observation conference. The detailed narration of the school head about the instructional performance of the teacher could be a little tedious. Male school heads, on the other hand, kept their observations short and direct to the point. Male school heads disliked long and intensive verbal discourse. They preferred to make their conversation short but addressed the main and salient features of instruction directly. Male school heads were not vocal. They were insistent but kept giving instructions more briefly. They manifested attributes to be masculine like insistence, authority, and power.

\subsubsection{Curriculum Leadership}

Male school heads carry out their functions differently from a female school heads. The female school heads gave more attention to details than their male counterpart. They also regularly made follow through activities. These characteristics help their teachers accomplish their tasks on time and helped them achieve their goal on time. However, with these characteristics the school head can be misinterpreted as extremely strict. She normally sees things that are not seen ordinarily. This could be attributed to the fact that a female school head has plenty of experiences running the operation of the family's internal affairs like children and budget.

\subsubsection{Staff Development}

All school heads key informants were noted as saying that they usually conduct activities for staff development. However, their ideas of staff development were limited to in-service trainings conducted at the end of the semester or at the end of the year. However, an observation was made that over and above the in-service trainings initiated periodically, they also had small activities in school that could be considered for this purpose. They differed in terms of intensity of interaction depending on leadership and interaction styles of school heads.

\subsection{Issues and Experiences Male and Female School Heads Confront in Dealing with Their Personnel}

This part presents a discussion on issues and challenges male and female school heads confronted in dealing with their personnel in the area of human resource management, physical facilities management, fiscal management, linkage management, data management, communication and conflict management, instructional supervision, curriculum leadership, and staff development. 


\subsubsection{Human Resource Management}

One of the challenges a school head could encounter was on how to ensure growth and development among staff, as regards to their monitoring and evaluation process. Female schools heads monitored strengths and weaknesses of their teachers based on the important function; while male school heads focused their monitoring on school development as a whole. Female schools heads monitored strengths and weaknesses of their teachers based on the important function; while male school heads focused their monitoring on school development as a whole. This implied that female school heads manifested a people-oriented organization in terms of educational management. On the contrary males did not indulge themselves in details on teachers' performance; but with the holistic result in general.

It was noted that female school heads were more sensitive to both needs of the learners and the teachers. This rejoined the findings of the Division of Human Relations of the Florida International University that giving recognition and awards would help the employees to be proud and responsible, appreciate their job, extend greater achievement, intensify commitment, enhance better relationship, endeavor expectations, support the climate of optimism, and experience joy in the job (Dawley, 2004).

\subsubsection{Physical facilities Management}

One important issue that confronted male and female school heads was to have a fully equipped learning environment. Through the school-based management program, a school head was empowered to generate resources and drew stakeholders to support the needs of school facilities and equipment. Though male school heads preferred to have simple classroom structures they tried their best to have fully equipped classrooms loaded with instructional materials. Male school heads also looked for some initiatives in order to realize their intended projects.

\subsubsection{Fiscal Management}

Another important role of a school head was preparing the school budgetary requirement, prioritizing needs for fund allocations and observing transparency and accountability of all financial transactions in school. Assigning teachers to help in the performance of this function was one main issue in choosing the right one to trust with this task. From the interviews conducted among the male and female school heads, male school heads preferred to have female school heads to handle finances in school for transparency and safety reasons. They experienced this area in doing budgeting and keeping money in the family.

\subsubsection{Linkage Management}

In public schools not all resources were provided. School heads had to be resourceful in generating the needed resources, thus the ability to establish good linkage with stakeholders was one big challenge for both male and female school heads in school. Female school heads have more facility to engage in networking to forge linkages with funding institutions, and welfare groups to find for grants for the improvement of the total life of the school that they managed in. In contrast, male school heads showed delegation in terms of trust, indicative of being a laissez faire leader.

\subsubsection{Data Management}

Another important issue confronted by the school heads was the ability to organize themselves in line with their decisions made, which were based on the data gathered and kept. This function could not be done well if without the support from the teachers who had the ability in this area in gathering data which were reliable and accurate. Data management would require certain accuracy and validation. This was made possible when maximum support of the school experts was properly channeled by the school heads. Channeling the important human resources in an organization necessitated effective supervision by the head of the school.

\subsubsection{Communication and Conflict Management}

In an interview with male and female schools heads, they expressed that in dealing with their teachers, open communication line was important to them. They solicited suggestions and feedbacks before arriving to a decision especially when it involved the teaching-learning process. According to them, the teachers should have a say in the process of making decisions with regards to school programs and activities. They believe that good governance is all about making every school personnel part of the institution.

This nuanced the school head's skill in democratic leadership, allowing the members of the organization responsible to build the school organization's culture and maintain the support of the total life of the school. 


\subsubsection{Instructional Supervision}

The challenge of improving students' academic achievements had something to do with the instructional supervision of the school head. The conduct of classroom observations, giving technical assistance, and clinical supervisions were important tasks of a school head.

Ensuring for the quality of instruction is one of the standards in the National Competency-based Teachers Standards or NCBTS to regulate the quality of instruction in the Philippines (Inocian, 2010). To achieve this, the school heads would evaluate the teachers regularly based on this standard. To help the teachers, one school head shared that she had organized activities such as Demonstration Teaching (DT), Peer Mentoring (PM), Learning Action Cell (LAC) sessions, gathering of student feedbacks, in order for her to provide remedy of the less performing teachers. She also gave emphasis to teachers on budget allocation for each student through the government downloaded fund, the MOOE (Maintenance of Operation and Other Expenses) was provided by the government to support the learners need and to achieve quality education through the effective delivery of instruction.

\subsubsection{Curriculum Leadership}

In the monitoring of the effective delivery of curriculum in the classroom several tasks had to be focused like the use of instructional strategies adopted by each teacher, the assessment of teachers' performance, and the technical assistance to be given to the low performing teachers. Some school heads shared that only few teachers adopted teaching strategies as learned and suggested during training and seminars they had attended.

School heads should provide constant monitoring of teachers in order for them to teach more effectively in line with the four major skills in the 21st century teaching such as skills for critical thinking, communication, collaboration, and creativity (Inocian, 2015).

\subsubsection{Staff Development}

Giving trainings and sending teachers to seminars was one important thing a school head should look into especially with fast changing generation of learners the 21st century learners. Teachers had to be equipped with knowledge, skills and attitude for them to deliver the expected desirable outputs in students' learning. One male school head said that untrained teachers sometimes learned from experience teachers. He still initiated school-based training for teachers. He conducted training at least twice a year during Midyear and Summer time. He said that:

This implied a people-centered management of an organization. This necessitated the observance of the optimistic climate of interaction and a positive learning environment. Fadeyi (2015), recognized the role of an educational institution to transform the society by empowering the teachers to enhance a humanistic school climate, i.e. more engaging and more productive in the school setting.

\section{Theory Generation}

Based on the qualitative data gathered, there were three propositions that were formed, which served the framework in extrapolating the theory.

\section{Proposition 1 - Administrative function could be gauged by physical facilities, teachers' behavior and students' development.}

Competence such as knowledge, skills, and attitudes of both male and female school heads served as the important components to become an efficient and effective school manager in carrying out administrative function. Administrative function which involved different areas of management such as human resource management, physical facilities, fiscal, linkage, data and communication management needed to be delivered by a leader who possessed certain skills in organizing, designating personnel which could work collaboratively and actively in planning and resourcing the needed facilities by the learners in order to establish a better learning performance and development.

The results of the study revealed that in schools where the administrators had good physical facilities, teachers' behavior and students' development produced an excellent school. This was supported by William Glasser's Quality School (1998). Both male and female school heads preferred good physical condition that contributed to the direct performance of the student and improve teachers' competence, skills and attitude. 
The administrative function did not generate an income for the organization. It was a function that rendered a service, which provided specialized support to individuals and other organizations which enabled the later to be more cost effective (Quible, 2005).

Proposition 2 - Instructional leadership contributed to learning performance outcome and teachers competence.

Male and female school heads had the challenge of improving performance of the learner. School heads delivered instructional function to ensure that instructional goals would be achieved with excellence. Intensive classroom observation and giving technical assistance were important supervisory function of the school heads.

A school head, part of his/her instructional supervision was to give teachers technical assistance in improving teaching learning performance. A school head supervised curricula from preparation to delivery of assessment to ensure quality leaners' expected learning outcome. Teachers were provided with training and seminars for them to produce quality teaching learning experience with the learners.

This study revealed that school heads that had good instructional leadership performed well to have competent teachers and desirable students' learning performance. The efficient and effective leadership styles of the school heads affected the academic success of the students in attaining instructional success and educational leadership.

Instructional leadership was a learning focus, then learning for both students and adults, which were measured by improvement in instruction and the quality of student learning. Instructional leadership dwells with a team of leaders of where the principal is serving as a leader of leaders (Baas, 2006).

\section{Proposition 3 - Gender bears the administrative function and instructional leadership.}

Administrative function and leadership represented the two important aspects of management particularly for male and female school heads. Administrative management tagged as an organic function, not instruction in nature, which involved human resource management, physical facilities, fiscal, linkage, data, and conflict and communication management. It involved planning organizing and critical point in decision making for school and learning improvement. In organizing and planning, managerial skills in which male and female school heads practiced similarly in some aspects; but they differ in other areas of management depending upon their gender orientation, training, and experiences in managerial aspects.

On the other hand, school heads performed instructional leadership function which included instructional supervision, curriculum leadership and staff development. In the exercise of instructional supervision school heads concurred that teaching and learning process were conducted and delivered well. Intensified classroom observation and post conference were given to teachers appropriately.

On curriculum leadership school heads monitored the effective delivery of curricula in the classroom. It involved instructional strategies used by the teachers in delivering the lesson to the learners. School heads observed the assessment of learners' performance.

The school heads noted how the teachers adopted teaching strategies and techniques gained in the given orientation and training. They also focused in the assessment of teachers' performance.

In the exercise of instructional leadership function of school heads, gender had a major consideration given to difference in orientation experiences and personality-based characters. These served as potential barriers to effective leadership.

From this study conducted, it was revealed that male and female school heads showed task involving administrative functions concerned with the well-being of the school in the execution of the different areas of management, organizational function and overall structure .However, female school heads had more and profound ways of maintaining relationship, organized, nurturing, data driven and allowed teachers participation in decision making. The male school head performed function that required strength and powers and had little engagement in terms of social interaction and conversation.

In the exercise of instructional function both school heads were concerned on instructional success, staff efficacy, and professional development and significant academic outcome. However female school heads made instructional decision based on students need, gave more details in classroom observation, post conference and curriculum delivery. Male school head 
preferred to make conversation, classroom observation post conference direct to the point with manifested attributes of a masculine like image, insistence authority, and accuracy.

The difference between administrative and leadership function between male and female school head were attributed by their mental construct and cultural family orientations. There were male and female school heads who were found with almost the same amount of task-oriented leadership behavior even though female school heads were high in their interpersonal behavior than their male counterparts. It was revealed that both leaders in school show participative, democratic, team management and authoritative leadership; however, female school heads tend to use more participative leadership style while male school head often use team management (Odivilas, 2015).

\section{The Theory}

From the previously mentioned propositions, Tan's Gender Role Orientation Theory of Institutional Management emerged. This theory stated that human beings exhibited unique difference and sameness of male and female leaders in an organization, not only guided by their sexual or biological identification, but to social orientation that was nurtured in the family, in the school, and other social institutions. Gender orientation had been recognized as a mental construct and the way how leaders looked at things reflected their gender schema. The mind-set dictated the behavior for a decisive action necessary for effective leadership. Therefore, if gender as a construct emanated from one's unique personal identity, gender orientation created the modalities of the leaders' leadership. The supervisory styles of leaders could vary accordingly to their gender orientation. How male leaders handle administrative and instructional functions were different if compared to their female counterparts. These variations could be seen in their human resources, physical facilities, fiscal, linkage, data and communication and conflict management. Gender also played a role in the differences of how male and female leaders practiced instructional supervision, curricular leadership and staff development.

\section{Conclusion}

From the findings revealed in the study and the theory generated, administrative and instructional leadership styles of male and female school heads were influenced by their gender orientation. Male school heads had particularly a template of leadership different from the female school heads, subject to role expectations, experiences, and cultural limitations. Though, both male and female school heads shared similar goals and aspirations; but, their leadership execution and implementation varied, as attributed by the nurturance of their various social orientations.

\section{Recommendations}

The following recommendations were drawn after the conduct of the study:

a. Policy revisions in some areas will be required to suit with the varying needs of both sexes in the workplace to promote a gender sensitive environment.

b. Continuing education through trainings and scholarship will be initiated to ensure that members of the organization will continue to evolve in their belief and to move away from traditional stereotypes concerning management and leadership roles of men and women.

c. More activities of social engagement will be most necessitated among male school heads to ensure and perpetuate democratic processes in important decisions that affect the members' way of life in the school organization.

d. Since leadership practices are also influenced by personality template, it is recommended that intensive personality training be given to incoming school heads so that they will be oriented on the varying personality types that they may encounter in the workplace.

e. A strong feedback mechanism will be established as a corrective measure for unacceptable leadership practices in school.

Funding: This research received no external funding from any public or private entity or organization.

Conflict of Interest: The authors declare no conflict of interest in this research.

\section{References}

[1] Appelbaum, S. (2003). Gender and Leadership? Leadership and Gender? A Journey Through the Landscape of Theories. Leadership and Organization Development Journal, 24(1), 43-51.

[2] Bass, B. M. (2006). Leadership and Performance Beyond Expectations. New York: The Free Press. 
[3] Bass, B. M. (2008). Does the Transactional-Transformational Leadership Paradigm Transcend Organizational and National Boundaries? American Psychologist, 52, 130-139.

[4] Crotty, M. (2003). The Foundations of Social Research: Meaning and Perspectives in the Research Process, 3rd edition. London: Sage Publications. Dawley, D. (2004). Leader Succession: Does Gender Matter? The Leader and Organization Development Journal, 25(8), 678690.

[5] Eagly, A. (2002). Role Congruity: Theory of Prejudice Toward Female Leaders. Psychological Review, 109(3), 573-597.

[6] Fadeyi, V. T. (2015). Influence of Teachers' Welfare Scheme on Job Performance in Selected Kwara State Secondary Schools. Asia Pacific Journal of Education, Arts and Sciences, 2(4), 89.

[7] Gardiner, M. (2009). Gender Differences in Leadership Style, Job Stress, and Mental Health in Male and Female Dominated Industries. Journal of Occupational and Organizational Psychology, 72, 301-315.

[8] Glasser, W. (1998). The Quality School Teacher, Revised Edition. New York: Harper.

[9] Guba, L. (1989). Fourth Generation Evaluation. London: SAGE Publications.

[10] Harris, A. (2002). School Improvement: What's in it for Schools. New York: Psychology Press.

[11] Helgesen, S. (1990). The Female Advantage: Women's Ways of Leadership. New York: Doubleday.

[12] Hussey, R. (2009). Business Research: A Practical Guide for Undergraduate and Posgraduate Studies. New York: Macmillan International Higher Education.

[13] Inocian, R. (2015). Quadrant Modelling in Teaching (QMT): Responding to RA 10533 Salient Provisions. Asia Pacific journal of Education, Arts and Sciences, 2(4), 71-78.

[14] Inocian, R. B. (2010). Aesthetic Teaching Pedagogies, 3rd Edition. Cebu City: R2L2 Publishing.

[15] London, M. (2002). Leadership Development. New Jersey: Lawrence Erlbaum Associates, Inc.

[16] Manning, T. T. (2002). Gender, Managerial Level, Transformational Leadership, and Work Satisfaction . Women in Management Review, 17(5), 207-216.

[17] Maynard, M. (1994). Methods, Practice and Epistemology, in Mary Maynard and Jane Purvis (Eds.), Researching Women's Lives from a Feminist Perspective . London: Taylor and Francis.

[18] Odivilas, H. A. (2015). Educational Management Graduates' Personal Qualities, Work Values and Job Performance: The Related Learning Experience (RLE) Model. European Scientific Journal, 11(23), 184-198.

[19] Quible, Z. (2005). Administrative Office Management: An Introduction, 8th Edition. New Jersey: Jersey Pearson Education.

[20] Vecchio, R. P. (2002). Leadership and Gender Advantage. Leadership Quarterly, 13, 643-671.

[21] Wellington, J. (2000). Educational Research: Contemporary Issues and Practical Approaches . London: Continuum. 